\title{
BAG3 Gene
}

National Cancer Institute

\section{Source}

National Cancer Institute. BAG3 Gene. NCI Thesaurus. Code C105994.

This gene is involved in the regulation of both protein folding and apoptosis. 